\title{
Efek Sinergis Bahan Aktif Tanaman Obat Berbasiskan Jejaring Dengan Protein Target
}
Penulis
Nur Hilal A.Syahrir ${ }^{1}$, Farit Mochamad Afendi ${ }^{2 *}$, Budi Susetyo ${ }^{2}$
Afiliasi

\footnotetext{
${ }^{1}$ Program Studi Statistika Terapan, Sekolah Pascasarjana Institut Pertanian Bogor, Indonesia.

${ }^{2}$ Departemen Statistika, FMIPA, Institut Pertanian Bogor, Indonesia.
}

\section{Kata Kunci \\ $\rightarrow$ drugCIPHER-CS \\ $\vartheta$ jamu \\ ○ NIMS \\ - network target}

Diterima 9 Agustus 2015 Direvisi 6 September 2015 Disetujui 17 November 2015

*Penulis korespondensi Farit Mochamad Afendi Program Departemen Statistika FMIPA Institut Pertanian Bogor fmafendi@gmail.com

\section{Abstract}

Medicinal plants contain inherently active ingredients. Such ingredients are beneficial to prevent and cure diseases, as well as to perform specific biological functions. In contrast to synthetic drugs, which is based on one single chemicals, medicinal plants exert their beneficial effects through the additive or synergistic action of several chemical compounds. Those chemical compound act on single or multiple targets (multicomponent therapeutic) associated with a physiological process. Active ingredients combinations show a synergistic effect. This means that the combinational effect of several active ingredients is greater than that of individual one acting separately. A network target can be used to identify synergistic effects of plants active ingredients. The method of NIMS (Network target-based Identification of Multicomponent Synergy) is a computational approach to identify the potential synergistics effect of active ingredients. It also assessess synergistic strength of any active ingradients at the molecular level by synergy scores. We investigate these synergistic on a Jamu formula for diabetes mellitus type 2 . The Jamu formula is composed of four medicinal plants, namely Tinospora crispa , Zingiber officinale, Momordica charantia, and Blumea balsamivera. Our work succesfully demonstrates that the highest synergy scores on medicinal plants synergy can be seen in pairs of several active ingredients in Zingiber officinale. On the other hand, the synergy of pairs of active ingredients in Momordica charantia and Zingiber officinale posseses a relatively high score. The same occurs in Tinospora crispa and Zingiber officinale.

\section{Pendahuluan}

Pola penyakit di Indonesia bahkan di dunia telah mengalami pergeseran dari penyakit infeksi ke penyakit-penyakit metabolik degeneratif yang disebabkan oleh gangguan metabolisme tubuh akibat konsumsi berbagai jenis makanan yang tidak terkendali serta gangguan faal tubuh sejalan dengan proses degenerasi. 
Contoh penyakit metabolik degenaratif seperti diabetes, kolesterol, asam urat, batu ginjal, hepatitis, rematik, dsb. Penyakit-penyakit metabolik degeneratif lebih sesuai jika ditangani dengan obat yang memiliki lebih dari satu efek farmakologi (Katno dan Pramono 2008). Fenomena tersebut menyebabkan pergeseran paradigma pengobatan dari obat-obatan konvensional yang hanya melibatkan satu senyawa kimia tunggal dengan satu target (one drug-one target) menjadi pengobatan berbasis tanaman obat yang melibatkan banyak komponen senyawa kimia yang bekerja pada satu atau beberapa target (multicomponent-network target) (Li dan Zhang 2013).

Interaksi kombinasi bahan aktif pada obat multikomponen sangat mungkin terjadi. Kombinasi antar bahan aktif dapat menunjukkan efek sinergis atau efek antagonis. Kombinasi yang menguntungkan tentu saja ialah kombinasi yang memiliki efek sinergis pada bahan aktif. Kombinasi efek sinergis merupakan tujuan yang dikejar dalam pengembangan tanaman obat sehingga kajian efek sinergis antar bahan aktif menjadi perhatian khusus pada penelitian ini. Evaluasi mengenai sinergisme bahan aktif pada tanaman obat biasanya dilakukan secara eksperimental dalam pendekatan kasus per kasus. Meskipun beberapa metode eksperimental telah dapat dilakukan untuk menyaring kombinasi bahan aktif yang menguntungkan, evaluasi sinergis secara eksperimental membutuhkan biaya dan tenaga yang besar serta waktu yang relatif lama. Pendekatan komputasi muncul sebagai alternatif yang mampu mengakomodir data yang besar dengan lebih cepat serta dapat memberikan metode yang lebih menjanjikan dan diinginkan untuk studi obat multikomponen.

$\mathrm{Li}$ et al. (2011) mengusulkan pendekatan komputasi untuk melihat potensi efek sinergis antar kombinasi bahan aktif pada tingkatan molekular dengan menggunakan metode NIMS (Network target-based Identification of Multicomponent Synergy). NIMS merupakan bagian dari rangkaian jejaring farmakologi yang melihat intervensi bahan aktif pada sistem biologis yang kompleks sehingg metode NIMS merupakan metode yang tepat digunakan untuk melihat sinergi pasangan bahan aktif pada studi obat multikomponen. NIMS mengkuantifikasi kekuatan sinergis pasangan bahan aktif dengan mempertimbangkan keterkaitan mekanisme kerja obat yang melibatkan peran protein target serta peran penyakit. Li et al. (2011) menginisiasikan metode NIMS dan menunjukkan bahwa metode NIMS memiliki performa yang baik dalam mengkuantifikasi dan menyaring sinergisme bahan aktif pada formula TCM (Traditional Chinese Medicine). Beberapa penelitian sebelumnya menggunakan metode NIMS untuk mengungkap mekanisme kerja formula TCM pada penyakit tertentu seperti diabetes mellitus tipe 2 ( $\mathrm{Li}$ et al. 2014) dan penyakit rematik (Li et al. 2015). Penelitian ini merupakan langkah awal evaluasi sinergis bahan aktif dengan pendekatan komputasi menggunakan metode NIMS pada ramuan Jamu.

Pendekatan komputasi yang menghasilkan skor kekuatan sinergis pada bahan aktif tanaman obat selanjutnya perlu untuk diuji secara statistika. Metode resampling dengan teknik uji permutasi diterapkan pada penelitian ini untuk menangani masalah asumsi sebaran skor sinergis yang tidak menyebar normal dan tidak diketahui sebarannya (nonparamaterik). Uji permutasi tersebut menguji signifikansi skor sinergis sehingga skor sinergis menjadi lebih bermakna.

\section{Metode Penelitian}

\section{Data}

Penelitian ini berfokus pada ramuan jamu yang sedang dikembangkan di Pusat Studi Biofarmaka untuk pengobatan diabetes mellitus tipe 2 . Ramuan jamu terdiri dari empat tanaman yaitu tanaman Bratawali (Tinospora crispa), Jahe (Zingiber officinale), Pare (Momordica charantia), dan Sembung (Blumea balsamivera). Ramuan jamu tersebut merupakan hasil prediksi formula jamu baru yang berkhasiat sebagai antidiabetes oleh Nurishmaya (2014). Pengumpulan data dilakukan dengan mengumpulkan informasi dari berbagai sumber pangkalan data (Lihat Tabel 1).

\section{Metode Analisis}

Pada penelitian ini terdapat tiga tahapan penting: (1) prediksi jejaring protein target, (2) kuantifikasi efek sinergis, dan (3) uji signifikansi skor sinergis. Diagram alir pada penelitian ini dapat dilihat pada Gambar 1. 
Tabel 1. Daftar pangkalan data untuk analisis jejaring farmakologi.

\begin{tabular}{|c|c|c|c|}
\hline Data & Pangkalan Data & $\begin{array}{l}\text { Informasi yang diperoleh dari } \\
\text { pangkalan data }\end{array}$ & Hasil penelusuran data \\
\hline Senyawa & $\begin{array}{l}\text { KNApSACK family } \\
\text { dan } \\
\text { The Dictionary of } \\
\text { Natural Products } \\
\text { (DNP) }\end{array}$ & $\begin{array}{l}\text { Daftar senyawa alami yang terdapat } \\
\text { pada tanaman tertentu. (Running WE } \\
\text { 1993; Afendi et al. 2012). }\end{array}$ & $\begin{array}{l}595 \text { senyawa pada } 4 \\
\text { tanaman yaitu } 18 \text { pada } \\
\text { Bratawali, } 291 \text { pada Jahe, } \\
245 \text { pada Pare, dan } 41 \\
\text { pada Sembung. }\end{array}$ \\
\hline Bahan aktif & PubChem & $\begin{array}{l}\text { Informasi lebih rinci mengenai bahan } \\
\text { aktif berupa struktur kimia, nama } \\
\text { kanonik (Canonical SMILES), Nomor CID } \\
\text { (PubChem CID), serta aktifitas } \\
\text { farmakologisnya. (Wang et al. 2009). }\end{array}$ & $\begin{array}{l}595 \text { senyawa tersebut } \\
\text { ditelusuri dan diperoleh } \\
55 \text { senyawa sebagai } \\
\text { senyawa aktif yang } \\
\text { mempunyai aktifitas } \\
\text { farmakologis. }\end{array}$ \\
\hline $\begin{array}{l}\text { Interaksi } \\
\text { senyawa - } \\
\text { protein } \\
\text { target }\end{array}$ & PubChem BioAssay & $\begin{array}{l}\text { Daftar protein yang menjadi target dari } \\
\text { bahan aktif dengan identitas protein } \\
\text { sebagai "gi numbers" (Wang et al. } \\
\text { 2009). }\end{array}$ & $\begin{array}{l}\text { Terdapat } 2971 \text { interaksi } \\
\text { dari } 55 \text { bahan aktif yang } \\
\text { menuju } 416 \text { protein yang } \\
\text { menjadi target bahan } \\
\text { aktif. }\end{array}$ \\
\hline $\begin{array}{l}\text { Interaksi } \\
\text { antar protein } \\
\text { target }\end{array}$ & $\begin{array}{l}\text { Human Protein } \\
\text { Reference Database } \\
\text { (HPRD) }\end{array}$ & $\begin{array}{l}\text { Daftar protein yang saling berinteraksi } \\
\text { (Goel et al. 2012). }\end{array}$ & $\begin{array}{l}\text { Interaksi antar protein } \\
\text { (PPI) sebanyak } 37.080 \\
\text { dari } 9.650 \text { protein. }\end{array}$ \\
\hline $\begin{array}{l}\text { Integrasi } \\
\text { pangkalan } \\
\text { data }\end{array}$ & $\begin{array}{l}\text { biological DataBase } \\
\text { network (bioDBnet) }\end{array}$ & $\begin{array}{l}\text { Kumpulan informasi mengenai ID } \\
\text { protein target pada database yang } \\
\text { berbeda (Mudunuri et al. } \\
\text { 2009) }\end{array}$ & $\begin{array}{l}\text { Konversi ID protein target } \\
\text { pada PubChem berupa "gi } \\
\text { numbers" menjadi HPRD } \\
\text { ID. } \\
\text { Konversi HPRD ID menjadi } \\
\text { Uniprot ID untuk masing- } \\
\text { masing protein target. }\end{array}$ \\
\hline $\begin{array}{l}\text { Protein } \\
\text { target }\end{array}$ & $\begin{array}{l}\text { Universal Protein } \\
\text { Resource (UniProt) }\end{array}$ & $\begin{array}{l}\text { Informasi rinci mengenai protein target } \\
\text { termasuk keterlibatannya dalam } \\
\text { penyakit (Apweiler et al. 2004). }\end{array}$ & $\begin{array}{l}\text { Daftar gen dan fenotipe } \\
\text { yang terkait dengan } \\
\text { protein target. }\end{array}$ \\
\hline Fenotipe & $\begin{array}{l}\text { Online Mendelian } \\
\text { Inheritance in Man } \\
\text { (OMIM) dan Human } \\
\text { Phenotype Ontology }\end{array}$ & $\begin{array}{l}\text { Kumpulan informasi mengenai penyakit } \\
\text { pada gen/protein lebih rinci. (Hamosh } \\
\text { et al. 2005; Robinson dan Mundlos } \\
\text { 2010). }\end{array}$ & $\begin{array}{l}\text { Masing-masing protein } \\
\text { target ditelusuri daftar } \\
\text { fenotipe (penyakit) } 346 \\
\text { serta interaksi antar } \\
\text { protein target-fenotipe } \\
\text { sebanyak } 358 \text {. }\end{array}$ \\
\hline
\end{tabular}

\section{Prediksi jejaring protein target}

Zhao dan Li (2010) mengusulkan metode drugCIPHER-CS untuk memprediksi profil protein target dari bahan aktif. Pada prinsipnya, drugCHIPERCS melihat kedekatan bahan aktif terhadap protein target dalam skala genomik yang besar dengan mengkorelasikan informasi kemiripan struktur kimia bahan aktif pada ruang farmakologi dan interaksi antar protein pada tubuh manusia (PPI) pada ruang genomik. Metode ini didasarkan pada hipotesis bahwa (i) obat dengan kemiripan struktur yang sama 


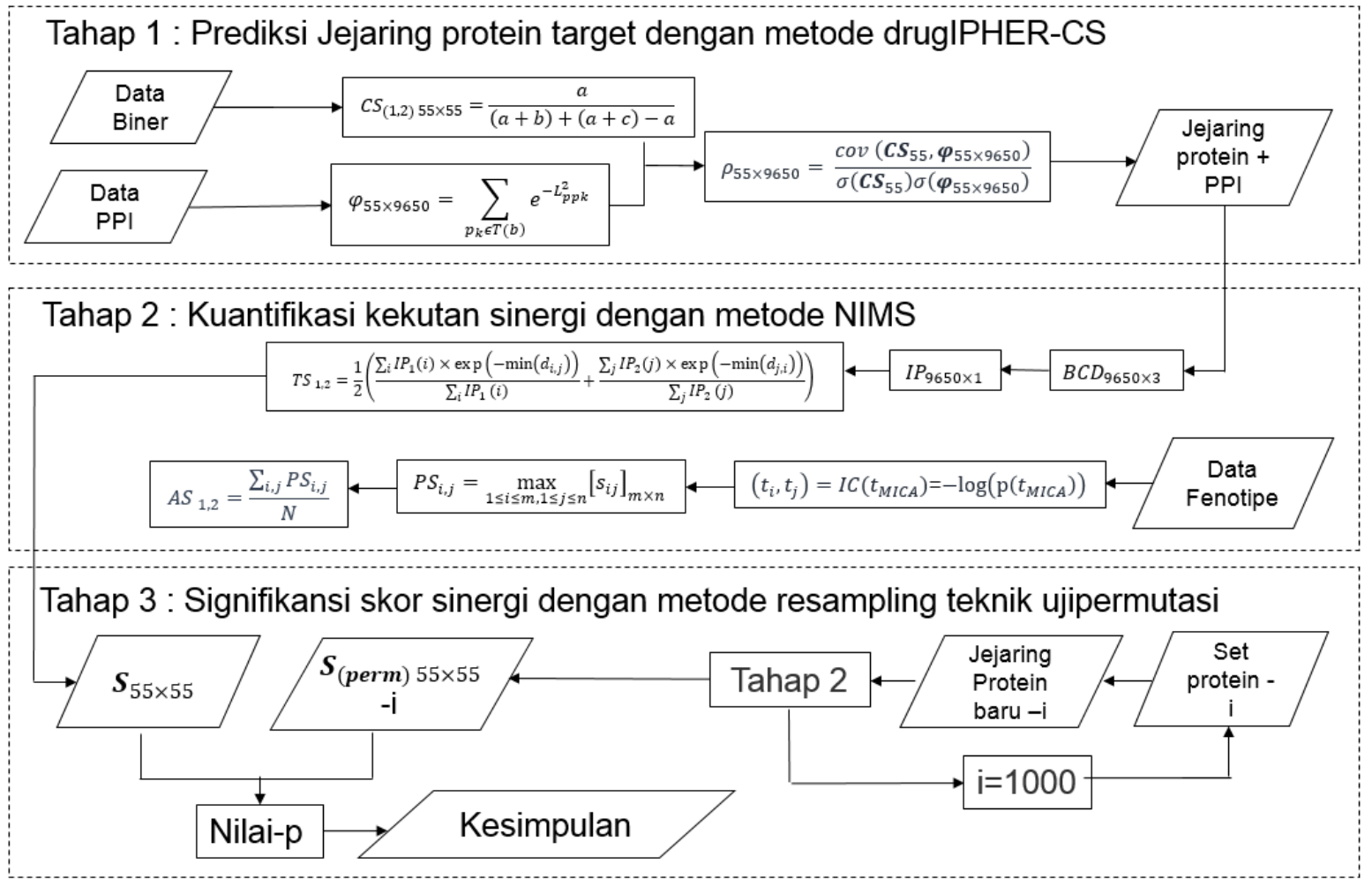

Gambar 1. Diagram alir penelitian. Kajian efek sinergis bahan aktif pada tanaman obat dilakukan dengan tiga tahapan.

cenderung mengikat protein yang terkait (ii) hubungan fungsional antara protein dapat diukur dengan jarak pada jejaring interaksi protein. Profil protein target dari tiap bahan aktif dihitung dari skor concordance

$$
\rho_{b p}=\frac{\operatorname{cov}\left(\operatorname{CS}_{b,} \varphi_{b p}\right)}{\sigma\left(\operatorname{CS}_{b}\right) \sigma\left(\varphi_{b p}\right)}
$$

dimana $\boldsymbol{C S}_{b}$ merupakan matriks kemiripan struktur kimiawi antar bahan aktif yang diukur dengan menggunakan koefisien Tanimoto pada data biner. Data biner dihasilkan dari dekomposisi 4860 substruktur sidik jari molekuler Klekota-Roth berdasarkan ada atau tidaknya substruktur tersebut. $\varphi_{b p}$ merupakan matriks kedekatan antara protein $p$ dan bahan aktif $b$ dengan basis jejaring PPI.

\section{Kuantifikasi efek sinergis}

NIMS merupakan salah satu pendekatan komputasi untuk mengidentifikasi pasangan agen sinergis pada tingkat molekuler. NIMS mengintegrasikan dua aspek yaitu berdasarkan fitur topologi jejaring protein target bahan aktif dan kesamaan fenotipe (penyakit) dari protein target bahan aktif. Skor sinergis antar dua pasang bahan aktif diperoleh dari perkalian Topology Score (TS) dan Agents Score (AS) (Li et al. 2011).

TS berasal dari fitur topologi jejaring yang dibangun berdasarkan protein target bahan aktif dan interaksi antar protein. Ide dasar dari topology score adalah dengan melihat kedekatan bahan aktif berdasarkan kedekatan protein penting dari masingmasing bahan aktif dalam jejaring protein target. TS dapat diperoleh dengan persamaan:

$$
T S_{1,2}=\frac{1}{2}\left(\frac{\sum_{\mathrm{i}} I P_{1}(i) \times \exp \left(-\min \left(d_{i, j}\right)\right)}{\sum_{\mathrm{i}} I P_{1}(i)}+\frac{\sum_{j} I P_{2}(j) \times \exp \left(-\min \left(d_{j i}\right)\right)}{\sum_{j} I P_{2}(j)}\right)
$$

dimana $I P_{1}(i)$ merupakan dari protein target dari bahan aktif-1 dan $I P_{2}(j)$ merupakan dari protein target dari bahan aktif-2 yang dihitung dengan 


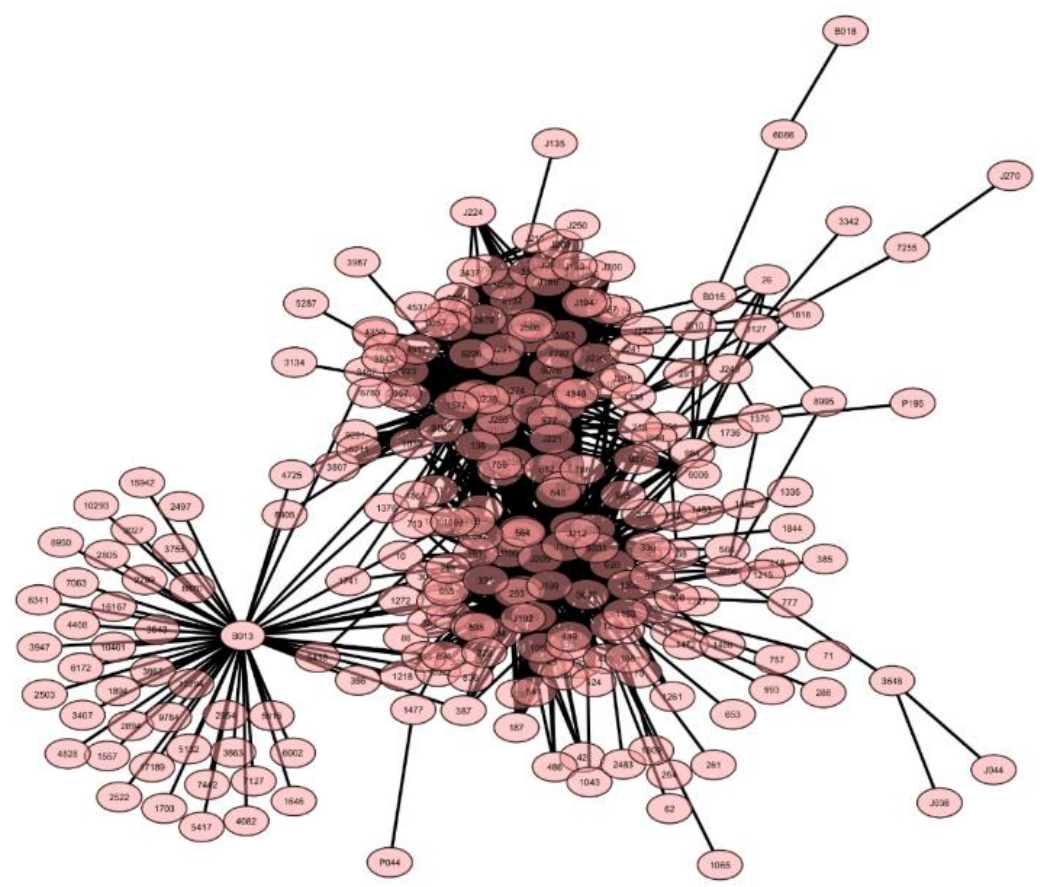

Gambar 1. Jejaring bahan aktif-protein target. Jejaring terdiri kumpulan bahan aktif dan protein target yang dilambangkan sebagai sebuah node dengan bentuk lingkaran. Interaksi bahan aktif dan protein target dilambangkan dengan garis yang menghubungkan antar node disebut sebagai edge.

mengintegrasikan degree, betweenness, dan closeness melalui analisis komponen utama (AKU). Fungsi eksponensial negatif digunakan untuk memboboti interaksi dua protein target

berdasarkan panjang lintasan terpendek. $\min \left(d_{i, j}\right)$ merupakan lintasan terpendek dari protein target-i dari bahan aktif-1 terhadap semua protein target-2, sementara $\min \left(d_{j, i}\right)$ merupakan lintasan terpendek

dari protein target-j dari bahan aktif-2 terhadap semua protein target-1. AS digunakan untuk mengukur nilai kesamaan antar pasangan bahan aktif berdasarkan fenotipe (penyakit) yang dihasilkan dari produk gen (protein target). Pasangan bahan aktif dengan mekanisme kerja yang independen namun mengobati penyakit yang sama akan lebih cenderung untuk menghasilkan efek sinergis. Jika protein target terdokumentasi memiliki eksperesi genetik berupa fenotipe dalam pangkalan data OMIM, fenotipe ini akan diidentifikasi sebagai agen fenotipe untuk agen yang diberikan. AS untuk pasangan bahan aktif-1dan bahan aktif-2

$$
A S_{1,2}=\frac{\sum_{i, j} P S_{i, j}}{N}
$$

dimana $P S_{i, j}$ adalah nilai kesamaan antara fenotipe-i dari bahan aktif-1 dan fenotipe-j dari bahan aktif-2, dan $\mathrm{N}$ adalah jumlah total pasangan fenotipe. Kesamaan fenotipe dihitung menggunakan konsep peluang pada diagram struktur Human Phenotype Ontology.

\section{Uji Signifikansi skor sinergi}

Uji permutasi merupakan salah satu teknik untuk melakukan pengujian hipotesis dengan metode resampling pada data yang tidak memenuhi asumsi normal atau sebaran tertentu kecuali pengamatan yang menyebar independen dan identik pada sebaran hipotesis nol (Smyth dan Phipson 2010). Uji permutasi dapat digunakan untuk menguji signifikansi hubungan yang melibatkan dua peubah (korelasi, regresi, dan hubungan lainnya yang terdifinisi dengan jelas). Uji signifikansi pada skor sinergi dilakukan dengan metode uji permutasi.

Ide dasar uji permutasi pada dua peubah ialah dengan mengubah urutan salah satu peubah

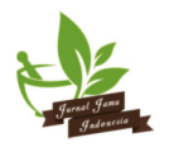


dengan pengacakan secara konsisten pada data yang diamati. Jika diasumsikan bahwa kedua peubah mempunyai hubungan, maka diharapkan setelah dilakukan pengacakan maka hubungan antar dua peubah tersebut hilang. Hipotesis nol menyatakan tidak ada hubungan antar dua peubah. Ketika pengacakan dilakukan berulang-ulang maka diperoleh sebaran statistik uji yang merupakan kondisi sebaran hipotesis nol. Sebaran hipotesis nol sebaiknya dibangun dalam jumlah yang besar. Nilai-p diperoleh dari proporsi data resampling permutasi dengan nilai statistik uji $\geq$ statistik amatan (Hesterberg et al. 2003).

\section{Hasil dan Pembahasan}

\section{Prediksi protein target dari bahan aktif}

Prediksi protein target diawali dengan tahapan pengumpulan data senyawa pada pangkalan data Knapsack dan DNP. 55 senyawa dari 595 senyawa diidentifikasi sebagai bahan aktif yang mempunyai aktifitas farmakologis yang terdokumentasi pada pangkalan data Pubchem. Protein target dari bahan aktif kemudian ditelusuri lebih lanjut sehingga diperoleh informasi pada Tabel 2.

Jejaring protein target awal merupakan jejaring yang terdiri dari 55 node sebagai bahan aktif dan 205 node sebagai protein target unik. Protein target unik berasal dari 332 protein target yang tereduksi menjadi 205 protein target disebabkan oleh adanya protein yang overlapping antara protein target yang berasal dari bahan aktif pada tanaman yang berbeda. Masing-masing bahan aktif menargetkan paling sedikit sebanyak satu dan paling banyak sebanyak 57 protein target. Hubungan interaksi bahan aktif dan protein target tersebut dapat direpresentasikan sebagai edge pada jejaring. Jumlah interaksi antar bahan aktif dan protein target yang diperoleh dari dokumentasi pangkalan data PubChem sebanyak 1297 . Prediksi protein target dari bahan aktif ramuan jamu diperoleh dengan menggunakan metode drugCIPHER-CS. Metode ini digagas oleh Zhao dan Li (2010) untuk memprediksi protein target dari bahan aktif dalam skala genomik yang besar dengan performa yang baik. Metode drugCHIPER-CS mengurutkan kemungkinan protein target tertentu yang menjadi target dari bahan aktif dengan mengkorelasikan kemiripan struktur kimiawi pada bahan aktif dan kedekatan antar protein target dalam jejaring PPI. Selanjutnya 100 protein target dengan nilai kemungkinan tertinggi dari masingmasing bahan aktif dihimpun dalam sebuah jejaring.

Jejaring prediksi protein target dibangun dari 55 node bahan aktif dan 1055 node protein target dalam 5500 interaksi. Hasil prediksi protein target dari bahan aktif tidak hanya berasal dari 205 protein target awal yang telah terdokumentasi menjadi target bahan aktif (Lihat Gambar 3). Bahan aktif S030 yang berasal dari tanaman Sembung diprediksi menuju protein target yang berbeda dari bahan aktif lainnya sehingga tersisih dari jejaring utama.

\section{Kuantifikasi efek sinergis}

Untuk melihat potensi efek sinergis dari kombinasi pasangan bahan aktif pada tingkatan molekuler digunakan metode NIMS. NIMS merupakan pendekatan baru yang digunakan untuk mengukur kekuatan sinergis dari pasangan bahan aktif tertentu dari tanaman dengan menentukan interaksi protein target dari bahan aktif tersebut pada jejaring PPI. Kajian NIMS diterapkan pada 55

Tabel 2. Daftar bahan aktif pada tanaman, protein target bahan aktif serta interaksinya.

\begin{tabular}{|cccc}
\hline \multicolumn{1}{c}{ Tanaman } & $\begin{array}{c}\text { Bahan } \\
\text { Aktif }\end{array}$ & Jumlah Protein Target & Interaksi Bahan Aktif - Protein Target \\
\hline Bratawali (Tinospora crispa) & 3 & 63 & 64 \\
Jahe (Zingiber officinale) & 46 & 146 & 1064 \\
Pare (Momordica charantia) & 3 & 28 & 28 \\
Sembung (Blumea balsamivera) & 3 & 95 & 141 \\
\hline Total & 55 & $332(205)$ & 1297 \\
\hline
\end{tabular}

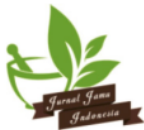


bahan aktif yang dikumpulkan secara manual pada empat tanaman yang telah diprediksi menuju. menargetkan protein target tertentu. Jejaring yang yang terbentuk pada NIMS adalah jejaring prediksi protein target pada jejaring PPI. Topologi jejaring pada NIMS digunakan untuk menghitung skor topologi yang merupakan ukuran kedekatan protein target dari masing-masing bahan aktif berdasarkan tingkat kepentingan protein tersebut dalam jejaring.

Tiga ukuran sentralitas yang digunakan untuk melihat skor tingkat pentingnya protein target sebagai sebuah node di dalam jejaring yaitu, betweenness, closeness, dan degree. Gambar 4 menunjukkan plot antara ketiga ukuran sentralitas pada 9.673 protein target pada jejaring PPI.

Ukuran degree menunjukkan fitur jejaring yang umum digunakan dan hanya mampu menangkap informasi lokal dari sebuah node dengan melihat tetangga terdekat sementara ukuran sentralitas betweenness tidak hanya berisi informasi lokal namun mengidentifikasi sebuah node dalam sebuah struktur jejaring global. Gambar 4 menunjukkan bahwa protein target dengan ukuran sentralitas betweenness yang tinggi juga mempunyai jumlah degree yang tinggi. Hal tersebut mengindikasikan adanya korelasi linear positif antara
Semakin penting protein target dalam jejaring maka PPI namun node yang menjadi pusat perhatian adalah 1055 node yang diperoleh dari Jejaring PPI dimanfaatkan untuk melihat node tersebut secara komprehensif dalam melihat skor kepentingan suatu node. Semakin penting protein target dalam jejaring maka semakin kuat pula efek yang dihasilkan oleh bahan aktif yang menargetkan protein tersebut.

ukuran betweenness dan ukuran degree pada jejaring ini. Semakin banyak jumlah edge atau jumlah protein target tetangga yang terhubung dengan protein target tertentu semakin besar kecenderungan protein tersebut mempunyai pengaruh pada struktur jejaring secara global. Ukuran yang lain yaitu ukuran kedekatan (closeness) merupakan ukuran seberapa dekat sebuah node tertentu terhadap node yang lainnya. Pada beberapa konteks, ukuran ini dapat dipahami sebagai ukuran seberapa cepat arus informasi yang dapat tersebar dari sebuah node tertentu ke semua node yang jauh pada jejaring. Gambar 4 menunjukkan bahwa efisiensi arus informasi dari protein target cenderung konstan.

Analisis komponen utama (AKU) digunakan untuk mengintegrasi ketiga ukuran tersebut menjadi satu skor yang mencerminkan tingkat kepentingan

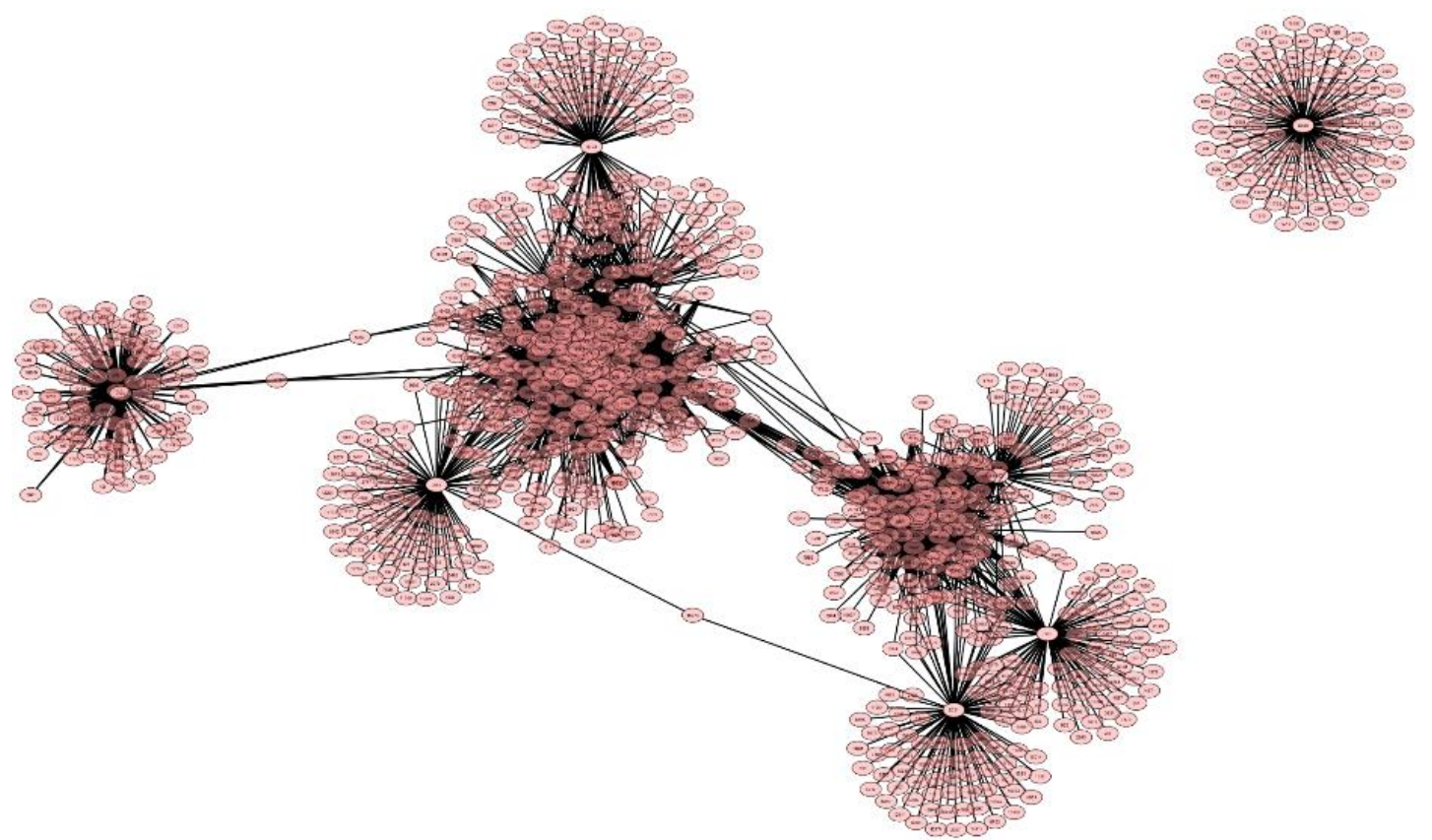

Gambar 3. Prediksi jejaring bahan aktif-protein target. Jejaring terdiri dari 55 bahan aktif dan 100 protein target dari masing-masing bahan aktif dengan skor concordance tertinggi. 


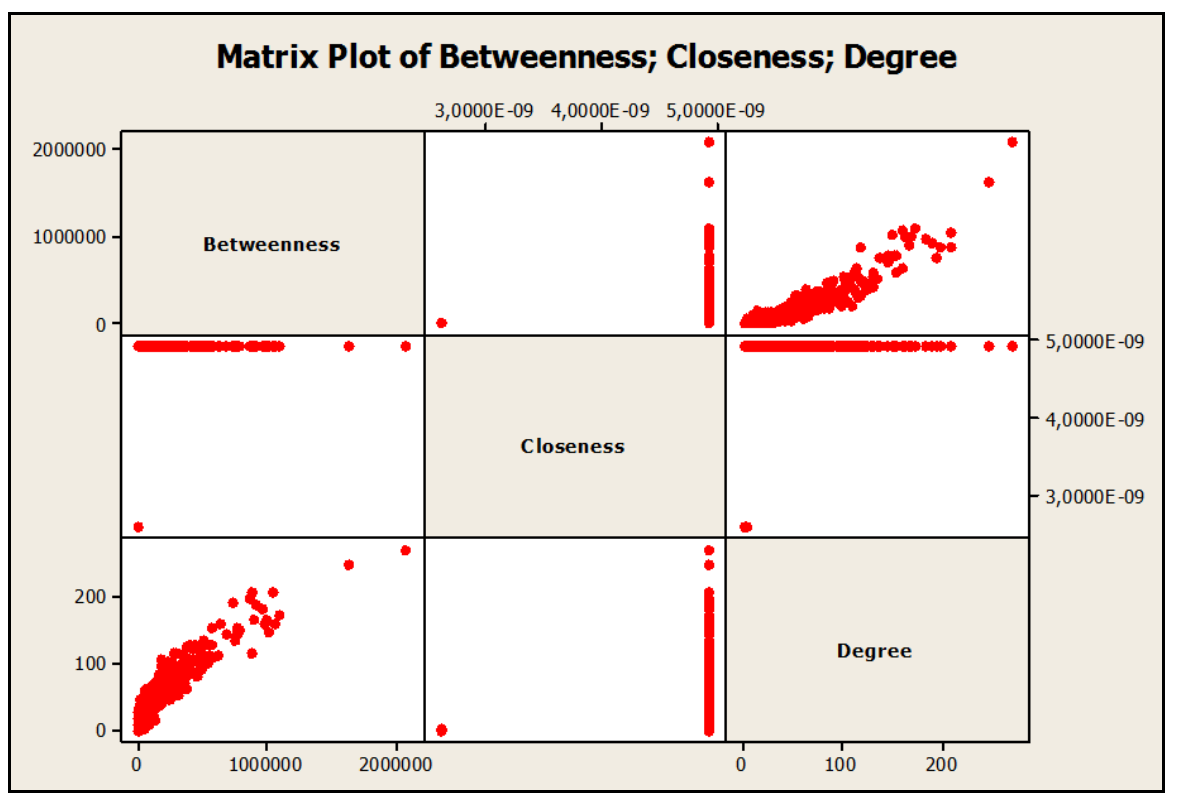

Gambar 4. Hubungan antara tiga ukuran sentralits pada jejaring yaitu: hubungan betweennes dan closeness, closeness dan degree, serta betweennes dan degree.

Tabel 3. Peringkat skor sinergi dengan Pare dan Bratawali sebagai tanaman utama

\begin{tabular}{llrr}
\hline Bahan aktif Utama & Kandidat bahan aktif & Skor Sinergi & Peringkat \\
\hline B013 & J127 & 0.126997677 & 13 \\
B013 & B018 & 0.088755617 & 20 \\
B013 & $\mathrm{J} 153$ & 0.08832469 & 21 \\
\hline B015 & J091 & 0.156777867 & 2 \\
B015 & J249 & 0.156777867 & 3 \\
B015 & J036 & 0.156632159 & 4 \\
\hline B018 & J127 & 0.139817208 & 10 \\
B018 & J270 & 0.101692438 & 14 \\
B018 & J153 & 0.096534603 & 17 \\
\hline P044 & P195 & 0.175887884 & 1 \\
P044 & P183 & 0.100362049 & 15 \\
P044 & S002 & 0.085856873 & 24 \\
\hline P183 & P195 & 0.06482849 & 33 \\
P183 & S002 & 0.015412255 & 45 \\
P183 & S031 & 0.011222444 & 69 \\
\hline P195 & S002 & 0.084028678 & 25 \\
P195 & S031 & 0.008765004 & 88 \\
P195 & S030 & 0.007337308 & 125 \\
\hline
\end{tabular}

protein target. Skor dengan satu komponen utama diperoleh dengan mengakomodir $63.6 \%$ keragaman dari tiga ukuran tersebut. Skor satu komponen utama menggambarkan skor kepentingan dari setiap protein target. Jarak terpendek antar protein target dari semua kemungkinan pasangan 

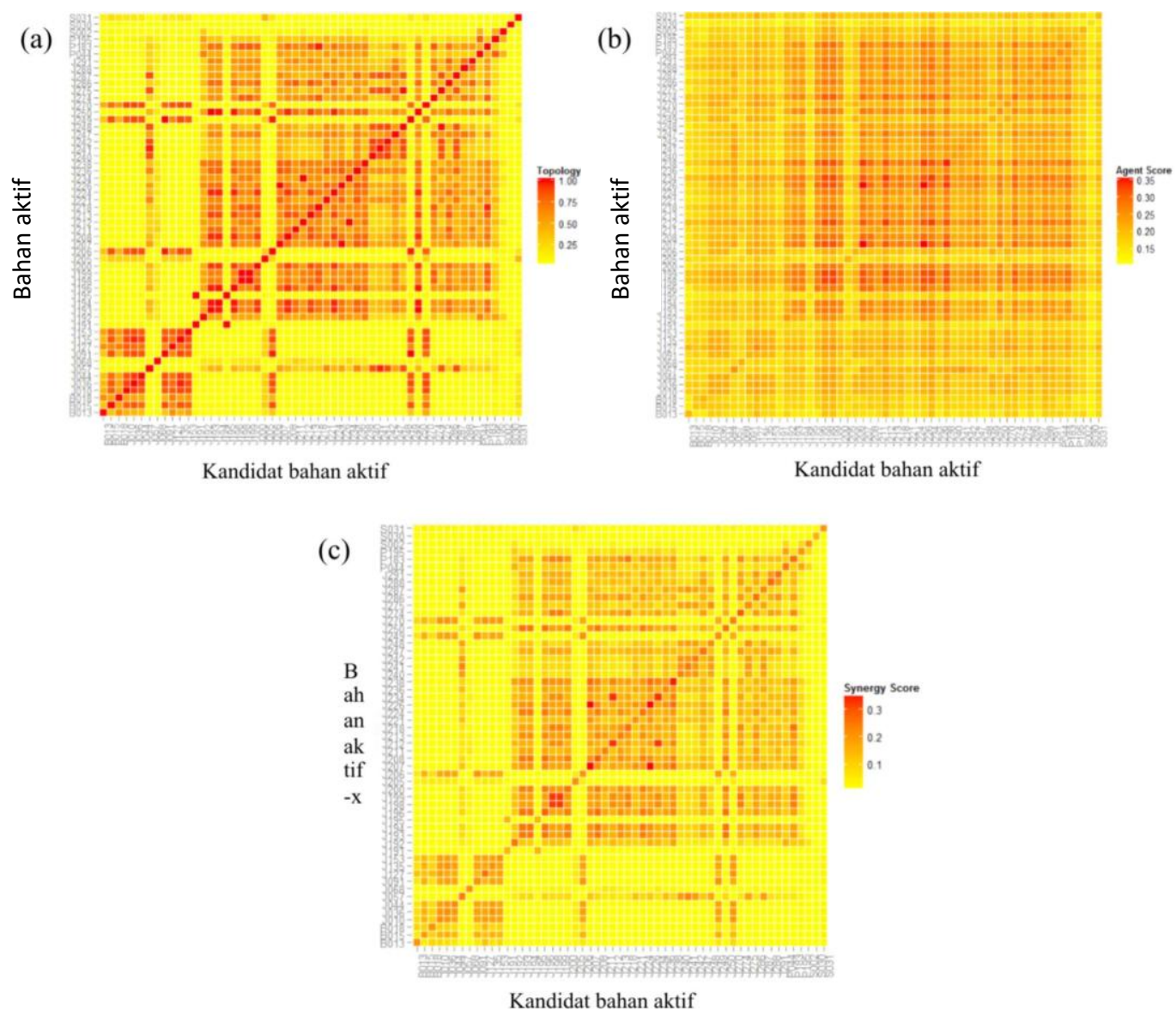

Gambar 5. Heatmap skor perhitungan pada NIMS. Skor berupa matriks 55x55 yang dilambangkan dengan warna. Warna merah menunjukkan skor tertinggi dan warna kuning menunjukkan skor terendah. (a) Matriks Topology Score (b) Matriks Agent Score (c) Matriks Synergy Score.

bahan aktif juga diukur untuk melihat kedekatan antara protein target nsatu dengan yang lain. Skor topologi mengintegrasi ukuran tingkat pentingnya protein target dan skor kedekatan antar protein target. Gambar 5(a) menunjukkan skor topologi dari kombinasi 55 bahan aktif. Pasangan kombinasi dari dua bahan aktif yang berbeda terdiri atas 1430 pasangan kombinasi. Gambar 5(a) menunjukkan bahwa skor topologi dari bahan aktif Sembung terhadap bahan aktif tanaman lain cenderung rendah. Prediksi jejaring menggambarkan posisi protein target dari bahan aktif Sembung relatif jauh daripada protein target dari bahan aktif lainnya. Namun terdapat indikasi kedekatan protein target Sembung dari bahan aktif tertentu terhadap bahan aktif yang berasal dari Pare. Selain dari hubungan protein target bahan aktif Pare dan Sembung di atas, kecenderungan protein target pada bahan aktif Pare memiliki kedeketan dengan protein target pada bahan aktif tanaman Jahe. Jumlah identifikasi bahan aktif Jahe yang lebih banyak dari bahan aktif lainnya menunjukkan sebagian besar pasangan bahan aktif tanaman Jahe mempunyai kedekatan protein target. Bahan aktif dari tanaman Bratawali menunjukkan kedekatan protein targetnya dengan tanaman Jahe dan antar bahan aktif Bratawali sendiri.

Selain melihat skor topologi, skor sinergi dapat ditelusuri melalui sejauh mana kemiripan pasangan bahan aktif tanaman obat dalam hal mengobati penyakit tertentu yang dikuantifikasi dengan Agent Score seperti pada Gambar 5(b). Kemiripan bahan aktif berdasarkan penyakit yang diobati memiliki nilai kemiripan yang lebih rendah dibanding berdasarkan skor kedekatan protein target. Informasi dari pangkalan data mengenai gen memang tidak selalu menunjukkan bahwa setiap gen atau 


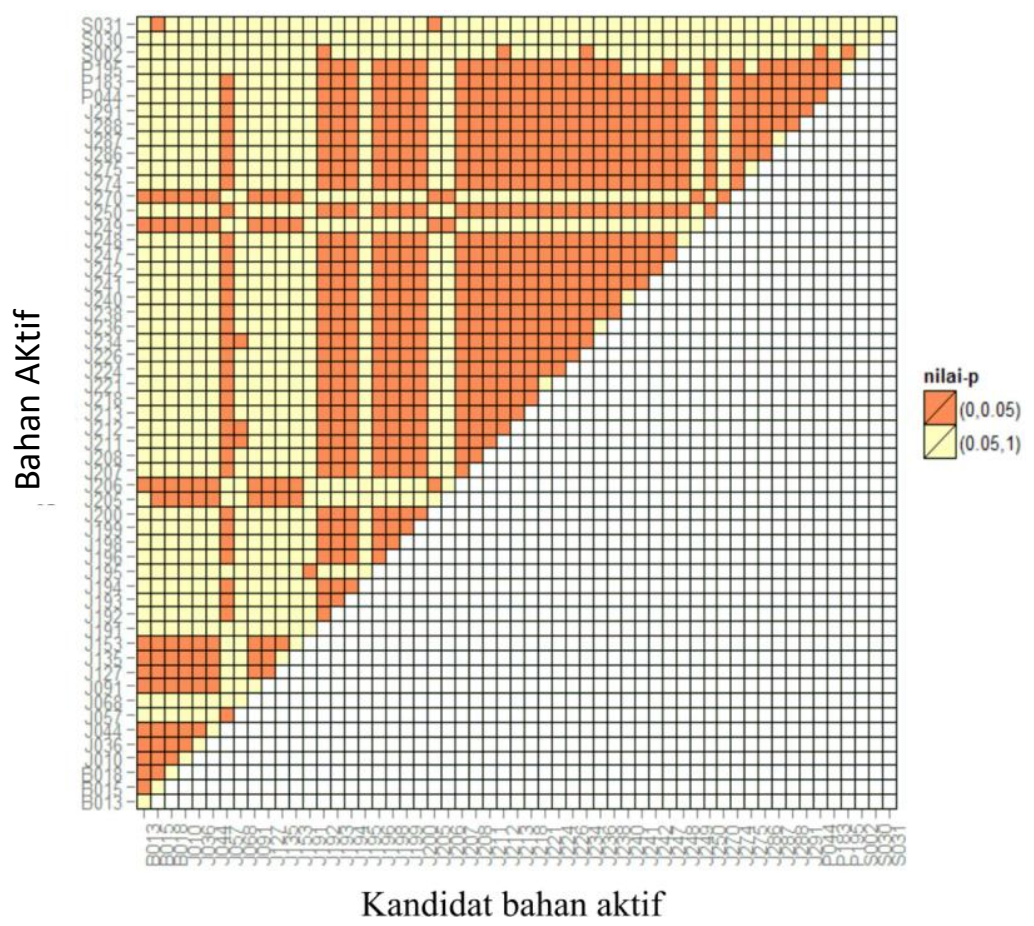

Gambar 6. Heatmap nilai-p pada uji permutasi efek sinergis bahan aktif tanaman obat. Warna gelap menunjukkan skor nilai-p $<0.05$ yang berati pasangan bahan aktif signifikan bersinergi. Warna terang menunjukkan skor nilai-p $\geq 0.05$ yang berarti pasangan bahan aktif tidak signifikan bersinergi.

produk gen memiliki atau mengeskpresikan fenotipe (penyakit) tertentu. Kemiripan bahan aktif dalam hal melihat kesamaan fenotipe ini lebih cenderung terlihat pada bahan aktif antar tanaman Jahe.

Dengan melihat dua aspek secara bersama dalam mengkuantifikasi sinergi antar bahan aktif diperoleh skor sinergi seperti pada Gambar 5(c). Skor sinergi yang diperoleh berada pada rentang (0.00251;0.353). Skor sinergi relatif rendah dibanding dengan skor topologi disebabkan sedikitnya kemiripan bahan aktif berdasarkan kelainan fenotipe oleh protein target dari bahan aktif. Skor sinergi tertinggi pada ramuan dapat dilihat pada pasangan bahan aktif antar tanaman Jahe. Sementara sinergi antar tanaman yang berbeda namun mempunya skor sinergi yang relatif tinggi adalah pasangan beberapa bahan aktif tanaman Jahe dan Pare, serta pasangan bahan aktif tanaman Bratawali dan Jahe.

Potensi skor sinergi antar pasangan bahan aktif dapat ditelusuri lebih rinci. Potensi skor sinergi antar bahan aktif dapat dengan Pare dan Bratawali sebagai tanaman utama dapat lebih jelas terlihat pada Tabel 3. Terdapat 324 pasangan bahan aktif dari tanaman Bratawali dan Pare terhadap semua bahan aktif pada empat tanaman. Berikut skor sinergi dari enam bahan aktif yang terdapat pada Bratawali dan Pare sebagai bahan aktif utama dengan 3 bahan aktif dengan peringkat teratas dari 55 kandidat bahan aktif yang lain.

\section{Uji signifikansi skor sinergi}

Uji signifikansi skor sinergi bertujuan untuk melihat apakah antar pasangan bahan aktif nyata bersinergi atau tidak. Skor sinergi yang diperoleh melalui pendekatan komputasi diuji menggunakan konsep uji permutasi dengan cara menyusun ulang dengan mengacak protein target yang menjadi target dari suatu bahan aktif. Penyusunan kembali dan pengacakan pada set protein target pada masingmasing bahan aktif menghasilkan statistik dari pengulangan pengacakan yang kemudian membentuk sebaran statistik dari skor sinergi. Nilai-p 
diperoleh untuk menguji signifikansi antar 55 pasangan bahan aktif pada ramuan jamu seperti pada Gambar 6. Pada taraf uji sebesar 5\% maka pasangan bahan aktif nyata bersinergi jika nilai-p $<0.005$. Hasil pengujian terhadap skor sinergi untuk skor yang relatif tinggi antar beberapa bahan aktif tanaman Jahe, antar pasangan beberapa bahan aktif pada tanaman Bratawali dan tanaman Jahe, serta antar pasangan bahan aktif pada tanaman Pare dan Jahe menghasilkan skor sinergi yang signifikan pada taraf uji nyata $5 \%$.

\section{Kesimpulan}

Metode NIMS dapat digunakan untuk mengkuantifikasi efek sinergi antar pasangan bahan aktif dan dapat divalidasi menggunakan uji permutasi. Implementasi skor sinergi juga dapat menunjukkan mekanisme kerja jamu secara komputasi. Skor sinergi yang relatif tinggi dan signifikan berdasarkan hasil uji permutasi antar pasangan bahan aktif pada tanaman penyusun ramuan jamu ditemukan pada pasangan bahan aktif antar tanaman Jahe. Efek sinergi antar tanaman yang berbeda namun mempunya skor sinergi yang juga relatif tinggi adalah pasangan beberapa bahan aktif tanaman Jahe dan Pare, serta pasangan beberapa bahan aktif tanaman Bratawali dan Jahe.

\section{Daftar Pustaka}

Afendi FM, Okada T, Yamazaki M, Hirai-Morita A, Nakamura $\mathrm{Y}$, Nakamura $\mathrm{K}$, Ikeda $\mathrm{S}$, Takahashi H, Altaf-Ul-Amin M, Darusman LK, Saito K, Kanaya S. 2012. KNApSAcK Family databases: Integrated metabolite-plant species databases for multifaceted plant research. Plant and Cell Physiol. 53(2):1-12.

Apweiler R, Bairoch A, Wu CH, et al. 2004. UniProt: the Universal Protein knowledgebase. Nucleic Acids Research. 32 (1):D115-D119.

Goel R, Harsha HC, Pandey A, et al. 2012. Human Protein Reference Database and Human Proteinpedia as resources for phosphoproteome analysis. Molecular BioSystems. 8(2):453-463.

Hamosh A, Scott AF, Amberger JS et al. 2005 Online Mendelian Inheriantace in Man (OMMIM), a knowladgebase of human genes and genetic disorders. Nucleic Acids Research. 33:D514D517.

Hesterberg T, Monaghan S, Moore DS, Clipson A, Epstein R. 2003. Bootstrap Methods and Permutation Tests. New York (US): W. H. Freeman and Company

Katno, Pramono S. 2008. Tingkat manfaat dan keamanan tanaman obat dan obat tradisional. Balai Penelitian Tanaman Obat Tawangmangu, Fakultas Farmasi, UGM. Diakses pada tanggal 09 Juni 2015 pada perpustakaan.depkes.go.id:8180/.../BK2008G105.pdf

Li S, Zhang B. 2013. Traditional Chinese medicine network pharmacology: theory, methodology and application. Chinese Journal of Natural Medicines. 11(2):0110-0120.

Li S, Zhang Bo, Zhang NB. 2011. Network target for screening synergistic drug combinations with application to traditional Chinese medicine. BMC Systems Biology. 5(1).1-13.

Li Y, Li R, Ouyang Z, Li S. 2015. Herb Network Analysis for a Famous TCM Doctor's Prescriptions on Treatment of Rheumatoid Arthritis. EvidenceBased Complementary and Alternative Medicine. 2015:1-9.

Li H, Zhao L, Zhang B, et al. 2014. A Network Pharmacology Approach to Determine Active Compounds and Action Mechanisms of GeGen-Qin-Lian Decoction for Treatment of Type 2 Diabetes. Evidence-Based Complementary and Alternative Medicine. 2014:1-12.

Mudunuri U, Che A, Yi M, Stephens RM. 2009. bioDBnet: the biological database network. Bioinformatics. 25(4):555-556.

Nurishmaya MR. 2014. Pendekatan bioinformatika formulasi jamu baru berkhasiat antidiabetes dengan ikan zebra (Danio rerio) sebagai hewan model [skripsi]. Bogor (ID): Departemen Kimia, Fakultas Matematika dan Ilmu Pengetahuan Alam, Institut Pertanian Bogor.

Running WE. 1993. Chapman and Hall dictionary of natural products on CD-ROM. Journal of Chemical Information and Computer Sciences. 33:934-935. 
Robinson PN, Mundlos S. 2010. The Human Phenotype Ontology. Clinical Genetics. 77: 525-534.

Smyth GK, Phipson B. 2010. Permutation P-values should never be zero: calculating exact $p$ values when permutations are randomly drawn. Statistical Applications in Genetics and Molecular Biology. 9:1-12.
Wang Y, Xiao J, Suzek TO, Zhang J, Wang J, Bryant SH. 2009. PubChem: a public information system for analyzing bioactivities of small molecules. Nucleic Acids Research. 2(8):1-11.

Zhao S, Li S. 2010. Network-based relating pharmacological and genomic spaces for drug target identification. PLOS ONE. 5(7):1-10. 